\title{
BIO-FERTILIZER EFFECTS OF BACTERIA ON MANGROVES
}

\author{
Kathiresan. $\mathbf{K}^{1}$, Masilamaniselvam. $\mathbf{M}^{2}$ \\ ${ }^{1}$ Centre of Advanced Study in Marine Biology, Annamalai University, Tamilnadu, India \\ ${ }^{2}$ Department of Biotechnology, Sathyabama University, Chennai, India. \\ E-mail : kathirsum@rediffmail.com
}

\begin{abstract}
Effect of two bacterial strains, Azotobacter vinelandii and Bacillus megaterium, was studied on the growth of two mangrove species, Rhizophora mucronata and Avicennia marina, raised for 60 days in soil under three levels of salinity $(0,17.5$ and $35 \mathrm{~g} \mathrm{l-1)}$. The bacillus treatment enhanced the shoot biomass by $171.6 \%$ in A. marina, while the azotobacter treatment increased it by $118.5 \%$, as compared to their respective controls. In Rhizophora mucronata, the root biomass was higher by $123.9 \%$ in bacillus-treated, and by $69.6 \%$ in azotobacter-treated than in control. Bacillus megaterium was found to be more potent microbial fertilizer than Azotobacter vinelandii in stimulating growth of the mangroves.
\end{abstract}

KEYWORDS: Biofertilizer, Azotobacter vinelandii, Bacillus megaterium, mangroves

\section{INTRODUCTION}

Biofertilizers are the live or latent cells of beneficial microorganisms, which augment the availability of nutrients to the plants. The beneficial microorganisms are rhizobium, azotobacters, azospirillum, cyanobacteria, phosphobacteria and mycorrhiza. Among these, azotobacters and phosphobacteria play major role in the supply of nutrients and in the plant growth promoting activities. However, these bacteria are present in low populations in the natural environment [1]. Hence, they are multiplied artificially and incorporated in to the agricultural lands in the form of biofertilizers. A lot of research work is available on the microbial biofertilizers in agriculture practices. However, only dearth of work is available for mangroves with regard to microbial biofertilizers. Therefore, the present study has been made to evaluate the bio-fertilizer effect of Bacillus megaterium and Azotobacter vinelandii, isolated from mangrove sediments, on mangrove seedlings.

\section{MATERIALS AND METHODS}

Azotobacter vinelandii and Bacillus megaterium, isolated from the mangrove sediments along the Vellar estuary (Lat. $11^{\circ} 29^{\prime} \mathrm{N}$; Long. $79^{\circ} 46^{\prime} \mathrm{E}$ ), were cultured in the Winogradsky's medium for the azotobacters, and the Pikovskaya's medium for bacillus. These cultures were incubated at $28 \pm 2^{\circ} \mathrm{C}$ for 5 days on a shaker.

The azotobacter strain was tested for IAA production [2] and for nitrogen fixation by using acetylene reduction assay in a gas chromatogram. The bacillus strain was tested for its activity of phosphate solubilisation [3].

Preparation of microbial biofertilizer: Farmyard manure (FYM) (passing through 100- $\mu$ m mesh sieve) was neutralized with commercially available calcium carbonate and autoclaved at $15 \mathrm{lbs}$ pressure for $4 \mathrm{~h}$. After cooling the FYM, the culture broth with microbial count of 109 cells ml-
1 was blended with the FYM. The final moisture content of 35-40 per cent on wet basis was maintained. In the process of mixing, the broth was sprayed on to FYM and cured in trays for $2-5$ days at $24^{\circ} \mathrm{C}$. The product was again milled and packed in polyethylene bags.

Biofertilizer experiment: Healthy propagules of Rhizophora mucronata and Avicennia marina were collected along with their native soil from the Pichavaram mangrove forest (Lat. $11^{\circ} 27^{\prime} \mathrm{N}$; Long. $79^{\circ} 47^{\prime} \mathrm{E}$ ), situated along the southeast coast of India. They were raised in polybags under nursery of our Centre. Soil in the polybags was mixed with biofertilizer at a rate of $10 \mathrm{~g}$ per $\mathrm{kg}$ of soil either with $A$. vinelandii, or $B$. megaterium, and or mixed cultures of these two bacteria $(5 \mathrm{~g}+5 \mathrm{~g})$. The polybags were irrigated separately with freshwater, diluted $(17.5 \mathrm{~g} \mathrm{l}-1)$ and undiluted seawater $(35 \mathrm{~g} \mathrm{l}-1)$. Control was maintained without addition of any biofertilizers in to the soil. Five replicates of propagules were maintained for each treatment. After 60 days of the experiment, plant height, shoot biomass and root biomass of the mangrove seedlings were recorded.

\section{RESULTS}

Studies revealed that Azotobacter vinelandii fixed nitrogen at $2.93 \mathrm{nM} \mathrm{C} 2 \mathrm{H} 4$ per $\mathrm{ml}$ per hour and it also produced $2.688 \mathrm{mg}$ of IAA per liter of culture, while Bacillus megaterium showed its ability to solubilize the phosphate at $0.141 \mathrm{mg}$ per liter of culture.

In Rhizophora mucronata, the bacterial treatment increased the shoot height growth at different levels of salinity. This effect was higher by $44.2 \%$ in the bacillustreated seedlings grown under $35 \mathrm{~g} \mathrm{l-1}$ salinity (Figure 1), by $39.6 \%$ in the mixture treated seedlings raised under $17.5 \mathrm{~g} \mathrm{l}-1$, and by $28.1 \%$ in the azotobacter-treated seedling under $35 \mathrm{~g} \mathrm{l}-1$, than their respective controls (Table 1). 
The bacillus increased the shoot biomass by $120.2 \%$ in the seedlings of $R$. mucronata grown under the salinity of $35 \mathrm{~g} \mathrm{l}-1$ (Figure 1) Azotobacter and mixed culture increased the shoot biomass by $96.2 \%$ and $58.7 \%$ respectively, under $35 \mathrm{~g} \mathrm{I-1} \mathrm{salinity} \mathrm{(Table} \mathrm{1;} \mathrm{Fig.} \mathrm{1).}$

The bacterial treatment significantly enhanced the root biomass in $R$. mucronata. The enhancement was $123.9 \%$ in the bacillus-treated seedlings grown in $35 \mathrm{~g} \mathrm{l-1}$ (Figure 1) and $119.5 \%$ under freshwater condition. The azotobacter-treated seedlings raised in $35 \mathrm{~g} \mathrm{l-1}$ (Figure 1) and freshwater showed higher root biomass by $69.6 \%$. The mixed culture exhibited $61.5 \%$ higher root biomass in the seedlings grown under $17.5 \mathrm{~g} \mathrm{l}-1$. All the growth parameters were statistically significant between the treatments, but not between the salinity levels (Table 1).

In Avicennia marina, the bacterial inoculation increased the shoot height growth at different levels of salinity. This effect was higher by $57.72 \%$ in the bacillustreated seedling grown under $35 \mathrm{~g} \mathrm{l-1}$ salinity (Figure 1 ), by $38.3 \%$ in the mixed culture treated seedlings raised under $17.5 \mathrm{~g} \mathrm{l}-1$, and by $30.1 \%$ in the azotobacter-treated ones under freshwater condition, than their respective controls (Table 1).

The bacillus and azotobacter increased the shoot biomass respectively by $171.6 \%$ and $153.7 \%$ in the seedlings of $A$. marina grown under the salinity of $35 \mathrm{~g} \mathrm{l-1}$ (Figure 1). The mixed cultures increased the shoot biomass by $118.51 \%$ in the seedlings raised under freshwater (Table 1).

The bacillus, mixed culture and azotobacter enhanced the root biomass respectively by $162.8,106.9$ and $74.4 \%$ in the seedlings grown under $35 \mathrm{~g} \mathrm{l-1(Figure} \mathrm{1).} \mathrm{All} \mathrm{the} \mathrm{growth}$ parameters were statistically significant between the treatments, but not between the salinity levels (Table 1).

\section{DISCUSSION}

Azotobacters as biofertilizer: The azotobacters are known to improve seed germination and plant growth in several crops (4-7). However, only a few studies are available on the biofertilizer effect of azotobacters on mangroves. Ravikumar (8) has investigated the biofertilizer effects of azotobacters isolated from the Pichavaram mangrove forests, on the growth of mangrove seedlings. Purushothaman (9) has also investigated the influence of azotobacters isolated from the Gulf of Mannar, on the growth and biomass production in mangrove seedlings. Both the workers have recorded that the azotobacters enhanced the growth of mangrove seedlings, as observed in the present study. However, the present work shows better results (Table 1; Figure 1). The promotory effect of Azotobacter vinelandii may be attributed to several reasons. The bacterial strain is capable of fixing atmospheric nitrogen and making it available to the mangrove seedlings $(8,9)$ and it also produces phytohormone - IAA, which helps in promoting growth $(8,10)$. This experimental result is in agreement with the field observation that seedlings of Rhizophora species grow luxuriant in the rhizosphere soil that is rich in azotobacters (11).

Fig. 1a,b60-day old seedlings of Rhizophora mucronata (1a) and Avicennia marina (1b) inoculated with Azotobacter vinelandii (A), Bacillus megaterium (B), mixture $(A B)$ and uninoculated control $(C)$ grown at $35 \mathrm{~g} \mathrm{l-1}$ salinity.

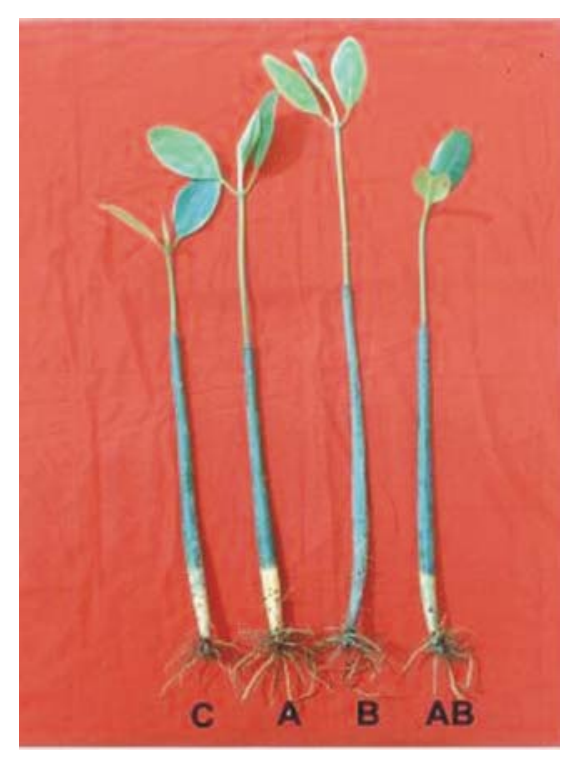

Fig. 1.a

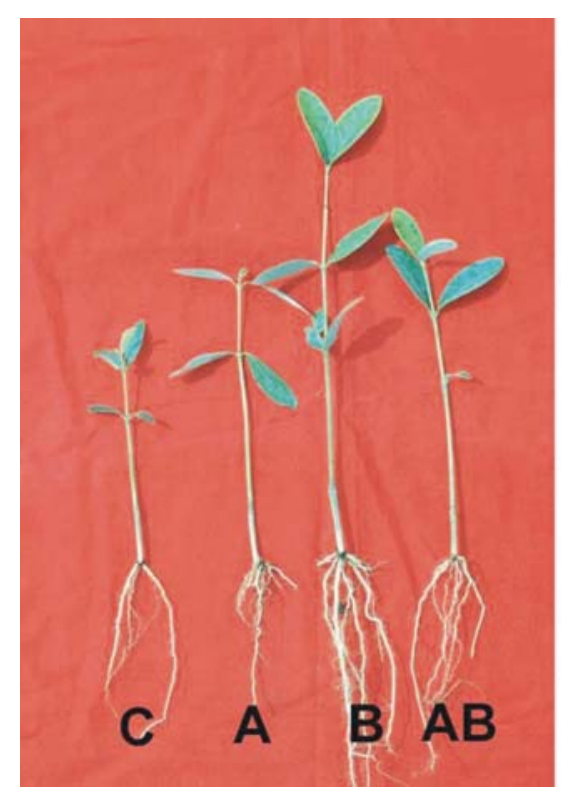

Fig. 1.b 
Bacillus as biofertilizer: The beneficial effects of the phosphate solubilizing bacteria on mangroves are reported here for the first time. However, such of the effects on crop plants are well-known. A commercial biofertilizer under the name 'phosphobacterin' has been prepared by incorporating Bacillus megaterium var. phosphaticum and is widely used in Russia and other East European countries and get crop yield increases of 5-10\% over corresponding controls. The Indian Agricultural Research Institute, New Delhi has conducted several field trials on the effect of phosphate solubilizing bacteria on wheat, maize and rice. The results have shown significant increase in yield over uninoculated controls under different agroclimatic conditions of the country 1. The phosphate solubilizing bacteria such as Bacillus species possess the ability to convert insoluble phosphates in the soil into soluble forms by secreting organic acids, such as formic, acetic, propionic, lactic, glycolic, fumaric, and succinic acids. These organic acids produced by the bacteria reduce $\mathrm{pH}$ and bring about the dissolution of bound forms of phosphate. Some of the acids may chelate with calcium and iron, resulting in effective solubilization of phosphates1,12.

In the present study, Bacillus megaterium enhances the growth and biomass in mangrove species, and this effect is much better than Azotobacter vinelandii. For example, B. megaterium has increased the root biomass in Rhizophora mucronata by $123.9 \%$, whereas Azotobacter vinelandii has increased it by $69.6 \%$ over control. The bacillus has increased the shoot growth of Avicennia marina by $57.7 \%$, whereas azotobacter has increased it by $30.1 \%$ over control (Table 1). However, the mixture of the two strains does not have better biofertilizer effect than the strains when used individually. This may be due to the antagonistic effect between the two strains.

Table 1.Influence of microbial strains on shoot growth, shoot biomass and root biomass in Rhizophora mucronata and Avicennia marina under different levels of salinity

\begin{tabular}{|c|c|c|c|c|c|c|}
\hline \multirow{2}{*}{$\begin{array}{l}\text { Salinity } \\
\left(\mathrm{g} \mathrm{|}^{-1}\right)\end{array}$} & \multicolumn{3}{|c|}{ Rhizophora mucronata } & \multicolumn{3}{|c|}{ Avicennia marina } \\
\hline & $\begin{array}{c}\text { Shoot height } \\
(\mathrm{cm})\end{array}$ & $\begin{array}{c}\text { Shoot } \\
\text { biomass }(\mathrm{g})\end{array}$ & $\begin{array}{c}\text { Root } \\
\text { biomass }(\mathrm{g})\end{array}$ & $\begin{array}{l}\text { Shoot height } \\
(\mathrm{cm})\end{array}$ & $\begin{array}{c}\text { Shoot } \\
\text { biomass }(\mathrm{g})\end{array}$ & $\begin{array}{c}\text { Root } \\
\text { biomass (g) }\end{array}$ \\
\hline 0 & $\begin{array}{l}17.88 \\
(15.5)\end{array}$ & $\begin{array}{l}1.56 \\
(6.8)\end{array}$ & $0.78(69.6)$ & $\begin{array}{l}19.54 \\
(30.1)\end{array}$ & $\begin{array}{c}0.354 \\
(118.5)\end{array}$ & $\begin{array}{l}0.226 \\
(48.7)\end{array}$ \\
\hline 17.5 & $\begin{array}{l}17.34 \\
(21.7)\end{array}$ & $\begin{array}{c}1.75 \\
(42.3)\end{array}$ & $0.67(28.8)$ & $\begin{array}{l}19.04 \\
(26.8)\end{array}$ & $\begin{array}{l}0.368 \\
(78.6)\end{array}$ & $\begin{array}{l}0.184 \\
(48.4)\end{array}$ \\
\hline 35 & $\begin{array}{l}21.34 \\
(28.1)\end{array}$ & $\begin{array}{l}2.04 \\
(96.2)\end{array}$ & $0.78(69.6)$ & $\begin{array}{l}17.04 \\
(29.1)\end{array}$ & $\begin{array}{l}0.244 \\
(82.1)\end{array}$ & $\begin{array}{l}0.15 \\
(74.4)\end{array}$ \\
\hline 0 & $\begin{array}{c}19.6 \\
(26.6)\end{array}$ & $\begin{array}{l}1.71 \\
(17.1)\end{array}$ & $\begin{array}{c}1.01 \\
(119.6)\end{array}$ & $\begin{array}{l}22.26 \\
(48.2)\end{array}$ & $\begin{array}{l}0.384 \\
(137.0)\end{array}$ & $\begin{array}{l}0.23 \\
(51.3)\end{array}$ \\
\hline 17.5 & $\begin{array}{l}17.93 \\
(25.9)\end{array}$ & $\begin{array}{l}1.98 \\
(60.9)\end{array}$ & $0.75(44.2)$ & $\begin{array}{l}22.28 \\
(46.6)\end{array}$ & $\begin{array}{l}0.376 \\
(82.5)\end{array}$ & $\begin{array}{l}0.226 \\
(82.3)\end{array}$ \\
\hline 35 & $\begin{array}{l}24.02 \\
(44.2)\end{array}$ & $\begin{array}{c}2.29 \\
(120.2)\end{array}$ & $\begin{array}{c}1.03 \\
(123.9)\end{array}$ & $\begin{array}{l}20.82 \\
(57.7)\end{array}$ & $\begin{array}{l}0.364 \\
(171.6)\end{array}$ & $\begin{array}{c}0.226 \\
(162.8)\end{array}$ \\
\hline 0 & $\begin{array}{l}16.9 \\
(9.2)\end{array}$ & 1.31 & $0.70(52.2)$ & $\begin{array}{l}15.66 \\
(4.3)\end{array}$ & $\begin{array}{l}0.214 \\
(32.1)\end{array}$ & $\begin{array}{l}0.172 \\
(13.2)\end{array}$ \\
\hline
\end{tabular}




\begin{tabular}{|l|c|c|c|c|c|c|}
\hline 17.5 & $\begin{array}{c}19.88 \\
(39.6)\end{array}$ & $\begin{array}{c}1.89 \\
(53.7)\end{array}$ & $0.84(61.5)$ & $\begin{array}{c}21.02 \\
(38.3)\end{array}$ & $\begin{array}{c}0.428 \\
(107.8)\end{array}$ & $\begin{array}{c}0.232 \\
(87.1)\end{array}$ \\
\hline 35 & $\begin{array}{c}18.00 \\
(8.4)\end{array}$ & $\begin{array}{c}1.65 \\
(58.7)\end{array}$ & $0.68(47.8)$ & $\begin{array}{c}16.36 \\
(23.9)\end{array}$ & $\begin{array}{c}0.34 \\
(153.7)\end{array}$ & $\begin{array}{c}0.178 \\
(106.9)\end{array}$ \\
\hline 0 & 15.48 & 1.46 & 0.46 & 15.02 & 0.162 & 0.152 \\
\hline 17.5 & 14.24 & 1.23 & 0.52 & 15.2 & 0.206 & 0.124 \\
\hline 35 & 16.66 & 1.04 & 0.46 & 13.2 & 0.134 & 0.086 \\
\hline & $4.24^{* *}$ & $112.38^{* *}$ & $8.27^{* *}$ & $14.97^{* *}$ & $8.08^{* *}$ & $9.57^{* *}$ \\
\hline & $2.88 \mathrm{NS}$ & $2.87 \mathrm{NS}$ & $0.19 \mathrm{NS}$ & $1.26 \mathrm{NS}$ & $2.19 \mathrm{NS}$ & $2.38 \mathrm{NS}$ \\
\hline
\end{tabular}

\section{ACKNOWLEDGEMENT}

The authors are thankful to the Annamalai University for providing the facilities.

\section{REFERENCES}

[1] Subba Rao, N.S., 1997, Biofertilizers in agriculture and forestry. Oxfords and IBH Publishing Co. Pvt. Ltd. New Delhi, 242.

[2] Gorden, S.A., Paleg, L.G., 1957, Quantitative measurement of Indole acetic acid. Physiologia Plantaram, 10, pp. 37-48.

[3] Geeta Singh, 1997, Estimation of phosphate solubilizing capacity of microorganisms, Training manual on Biofertilizers, IARI, New Delhi. 35.

[4] Brown, M.E., Burlingam, S.K., 1968, Production of plant growth substances by Azotobacter chroococcum. Journal of General Microbiology, 53, pp. 135-144.

[5] Barea, J.M., Brown, M.E., 1974, Effects on plant growth substances produced by Azotobacter paspali related to synthesis of plant growth regulating substances, Journal of Applied Bacteriology, 37, pp. 583-593.

[6] Rangarajan, M., Muthukrishnan, P., 1974, Effects of Azotobacter on growth and yield of Bhindi, Proc: 14th Annual Conference of Association of Microbiologist in India, Bangalore, 29.

[7] Patriquin, D.G., Dobereiner, J., Jain, D.K., 1983, Sites and process of association between diazotrophs and grasses. Canadian Jounal of Microbiology, 29, pp. 900-915.
[8] Ravikumar, S., 1995, Nitrogen-fixing azotobacters from the mangrove habitat and their utility as biofertilizers. Ph.D. thesis, Annamalai University, India.

[9] Purushothaman, A., 1999, Studies on bacterial ensemble in a developed vis-a-vis developing mangrove ecosystem. Ph.D. thesis, Annamalai University, India.

[10] Azeon R, Barea, J.M., 1975, Synthesis of auxins, gibberllins and cytokinins by Azotobacter vinelandii and $A$. beijerinckii to effects produced on tomato plants. Plantand Soil, 43, pp. 609-619.

[11] Kathiresan, K., Xavier Ramesh, M., Venkatesan, V., 1994, Forest structure and prawn seeds in Pitchavaram mangroves. Environmental Ecology, 12, pp. 465-468.

[12] Kundu, B.S., Gera, R., Sharma, N., Bhatia, A., Sharma, R., 2002, Host specificity of phosphate solubilizing bacteria. Indian Journal of Microbiology, 42, pp. 19-21.

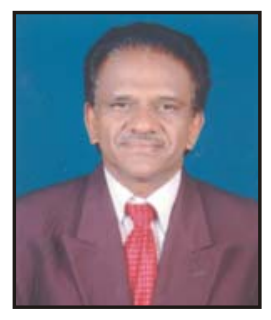

Dr. K. Kathiresan from the Centre of Advanced Study in Marine Biology of Annamalai University has spent practically 25 years of his research career in studying mangroves and its microbiology. He has conducted many international and national training programmes on mangroves. His 250 research publications have been highly valued. He is the recipient of several national and international awards including the highest Degree of Doctor of Science in marine biology. 